\title{
Effect of Different Animal Organic Manures on the Biometric and Nutrient Parameters of Coriandrum sativumL
}

\author{
${ }^{1}$ Maria Puspham Grace.M, ${ }^{2}$ Rajithra.R , ${ }^{3}$ V.Ilakkiya, \\ ${ }^{4}$ Dr. B. Dhanalakshmi \\ ${ }^{1234}$ Department of Zoology, Nirmala College for Women, Bharathiyar University, \\ Coimbatore-18
}

Corresponding author: Dr. B. Dhanalakshmi and V. Ilakkiya

Article DOI: https://doi.org/10.36713/epra7522

DOI No: 10.36713/epra7522

\begin{abstract}
In recent years, use of livestock manure and marine bio-waste has been advocated in integrated nutrient management (INM) system in vegetable crops. Poultry manure is an excellent organic fertilizer, is concentrated source of nitrogen and other essential nutrients. In the present study the culinary herb Coriandrum sativum which has medicinal property was selected as experimental plant whose biometric parameters were analyzed in different treatment pots amended with different organic poultry and fish manure. The productivity of Coriander is influenced by several factors such as soil, varieties, fertilizer management, and also various agro techniques used for growing crop. With this context in the present experimental study two animal wastes converted to organic manure by Eudrilus eugeniae-Worm into poultry and fish manure in organic farm of Rajapalayam District was purchased and amended in $2 \mathrm{~kg}$ garden soil in selected ratios namely $25 \%\left(T_{2}\right), 50 \%\left(T_{3}\right), 75 \%\left(T_{4}\right)$ and $100 \%\left(T_{5}\right)$. $\left(T_{1}\right)$ was maintained as control in which no amendment was made. Corainder seed were purchased from TNAU, Coimbatore. The experimental findings pertaining to the present investigation reveals the effect of poultry manure has been higher than fish manure on the growth parameters and NPK of coriander (Coriandrum sativum L.). So the ultimate goal is to develop farming systems that are productive, energy conserving, environmentally sound conserving of natural resources such as soil and water and thus ensure food safety and quality.
\end{abstract}

KEYWORDS: Manure, Coriander, Poultry and Eudrilus euginae

\section{INTRODUCTION}

Nutrient availability is critical in efficient agriculture production systems.

Conventional agriculture uses chemical fertilizers which have several possible negative side effects. These are often associated with soil degradation and depletion as well as water and soil pollution. (Grubinger, 1999) noted that chemical fertilizers are made up of minerals which dissolve rapidly in damp soil resulting in rapid availability of large doses of minerals to the plants. Furthermore, excessive use of urea fertilizer which contains nitrogen $(\mathrm{N})$ may lead to soil and groundwater contamination further affecting the environment. 
Modern research has identified alternative agricultural methods that lead to good yields and enhanced soil fertility without using chemical components. Organic agriculture is one of the agricultural forms that often depend on using green manure, compost, and biological pest management. India stands second in global fish production with an annual fish production of around 10 million metric tons. Around $85 \%$ of fish produced is consumed in the fresh form (DAHD, 2014) and 10.51 lakh tons is exported. India is home to more than 60 minor fishing harbors, around 1500 fish landing centers, 350 seafood processing factories and innumerable number of fish markets where a huge amount of processing waste is being generated. Fish marketing and processing operations produce waste in the solid form like fish carcasses, viscera, skin and heads. Quantum of waste generated through fish processing varies from $10 \%$ to $80 \%$ of the weight of the fish according to the processing activities. Presently in India, around 960 million tons of solid waste is being generated. By 2050, our country would need 9 times the area of land for dumping of wastes which we all know is not feasible taking into account the exponential population growth.

Coriander is one of the important spice crop grown throughout the world and botanically known as Coriandrum sativum Linn. It belongs to the family Apiaceae. It is mainly cultivated for its leaves as well as seeds. The productivity of Coriander is influenced by several factors such as soil, varieties, fertilizer management, and also various agro techniques used for growing crop. Intensive cultural practices are necessary to produce high yields and quality product. There are numerous factors that influence the nutrition in crops. These factors can be internal or genetic factors on the one hand and external factors on the other hand. Both types play significant roles in the nutrition processes that we can observe in crops. The efficient use of fertilizers is necessary for optimum growth and yield. Hence knowledge about the availability of nutrients in the soil is very essential. Plant analysis serves as an elegant tool for understanding the growth and physiology of the plant at various phases of its growth (Hartz and Hochmuth, 1996). Keeping these facts in view, a pot designed experiment was conducted with to study the effect of different organic manures and fertility levels on growth and nutrient quality of Coriandrum sativaum and also to find out the suitable combination of organic manure and fertility levels . 


\section{MATERIALS AND METHODS}

The study was conducted at the research lab of Post graduate Research Department of Zoology, Nirmala College Women, Coimbatore during 2020-2021.

\section{Preparation of Vermicompost}

Organic manure was prepared by using Eudrilus eugenia species of earthworms with poultry waste and fish waste as substrate at the Organic farm, Rajapalayam, Virudhunagar District. (Plate: 1)

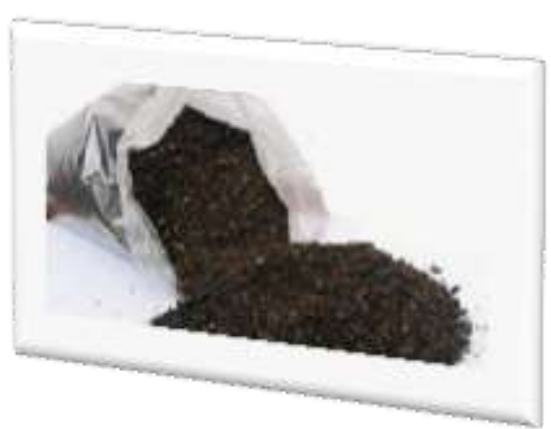

Plate:1 Eudrilus eugeniae -organic manure

\section{Scientific Classification of selected earthworm}

$\begin{array}{lll}\text { Kingdom } & : & \underline{\text { Animalia }} \\ \text { Phylum } & : & \underline{\text { Annelida }} \\ \text { Class } & : & \underline{\text { Clitellata }} \\ \text { Subclass } & : & \underline{\text { Oligochaeta }} \\ \text { Order } & : & \text { Haplotaxida } \\ \text { Family } & : & \text { Eudrilidae } \\ \text { Genus } & : & \text { Eudrilus } \\ \text { Species } & : & \text { E.eugeniae }\end{array}$

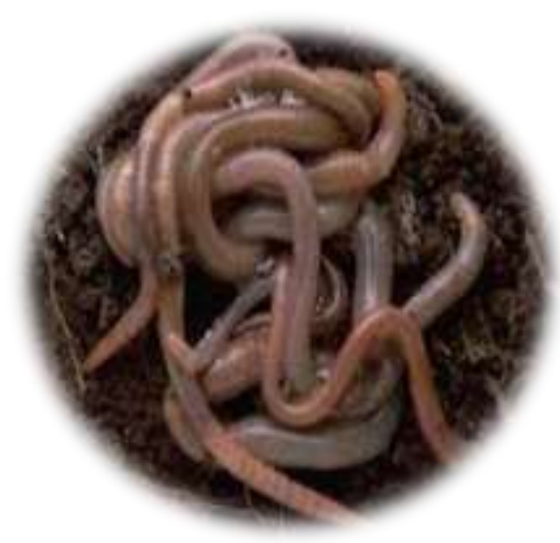

Plate:2 Eudrilus eugeniae-Worm

\section{Collection of Experimental Items}

The vermicompost was taken from the earthen pit from Nirmala College for Women. The seeds of Coriandrum sativum (Linn.) were collected from Tamilnadu Agricultural University of Coimbatore district. Poultry waste and fish waste was collected from local organic farm, Rajapalayam, Virudhunagar District. All the experimental pots were purchased from Town hall,Coimbatore. 


\section{Scientific Classification of selected plant species}

$\begin{array}{lll}\text { Kingdom } & : & \text { Plantae } \\ \text { Order } & : & \text { Apiales } \\ \text { Family } & : & \text { Apiaceae } \\ \text { Genus } & : & \text { Coriandrum } \\ \text { Species } & : & \text { C.sativum }\end{array}$

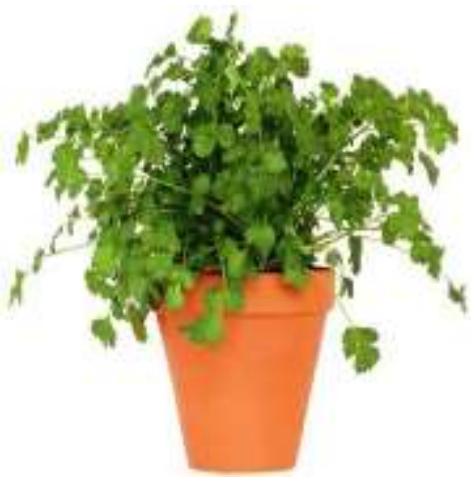

Plate:3 Coriandrum sativum Linn.

\section{Experimental Design}

A pot culture study was laid out in completely randomized design with three replications for each treatment. Each pot was uniformly filled with $2 \mathrm{~kg}$ of soil and treated with different combinations of Poultry manure and fish manure amended with garden soil. A pot with garden soil without any amendment was maintained for each treatment as control. All the other pots were amended with $25 \%, 50 \%, 75 \%$ and $100 \%$ of poultry manure in one experimental setup and other with $25 \%, 50 \%, 75 \%$ and $100 \%$ of fish manure. The following concentrations are as follows: $\left(\mathrm{T}_{1}\right)$ - Control, $\left(\mathrm{T}_{2}\right)-25 \%,\left(\mathrm{~T}_{3}\right)-50 \%,\left(\mathrm{~T}_{4}\right)-75 \%,\left(\mathrm{~T}_{5}\right)-100 \%$

\section{Treatment Methods}

About 30 seeds were sown in each pot and allowed to germinate. There was no incidence of pest or disease on coriander during the experiment. They were then thinned to 15 plants per pot. The pots were watered daily and holes were made at the base of the pot to prevent water logging condition. The plants were observed from germination time till $30^{\text {th }}$ day. The plants were uprooted on the $30^{\text {th }}$ day without any damage. The adhering soil particles were removed by washing gently with water and the water droplets were removed by blotting with the filter paper. Then these plants were used for the biometric observation and biochemical analysis.

\section{Prevention of Pest Infection}

$25 \mathrm{gm}$ of garlic was ground, added one liters of water and the mixture was sprayed on to plants to prevent the pest infection. 


\section{Experimental Structure}

No. of treatments -4

No. of replication -3

Design - CRD (Completely Randomized Design)

No. of pots -15

Period of pot culture -1 month.

\section{Biometric observations}

The fresh plants were used to determine the fresh weight, shoot length (measured from the point of first cotyledonary node to the tip of the longest leaves), root length (measured from the crown region of the plant to the tip of the root) and number of leaves.

\section{Morphometric characteristics}

Germination of Seeds: At 30 days after sowing the number of normal seedling germinated were counted and expressed in percentage. The germination percentage was calculated by using the formula outlined by IST (1995).

\section{Germination percentage $=$ number of seedlings/ total number of seed $\mathrm{X100}$}

Number of leaves per plant: The total number of leaves of in each of the five randomly selected plants was counted and recorded. The mean number of leaves per plant was worked out.

- Leaf Area: The five tagged plants were also used for leaf area measurement at harvest. The leaf area was measured with the help of leaf area meter. The average leaf area $\mathrm{cm}^{2}$ was recorded as mean value to calculate total leaf area $\mathrm{cm}^{2}$ per plant

Height of the plant: Five plants were randomly selected in each plot and tagged. The plant height was measured at harvest from base of the plant to tip of the main shoot by meter scale and average height of five plants were recorded as mean plant height $(\mathrm{cm})$.

Number of branches per plant: Total numbers of branches emerging from main stem of the plant were counted in each of the five randomly selected plants and the average was calculated per plant basis.

Length of the root: The root lengths of the root in each of the five randomly selected plants was measured from the root collar region to the tip of the root using centimeter scale and mean length was expressed in $\mathrm{Cm}$.

\section{Nutrient Parameters}

Determination of available nitrogen was done by alkaline permanganate method suggested by Subbiah and Asija (1956). The estimation of available P was done by using Olsen's extract ( $0.5 \mathrm{~N}$ sodium bicarbonates solution of $\mathrm{pH} 8.5)$ as referenced by Olsen et al. (1954). It was determined as stannous chloride reduced blue colour the extraction 
procedure adopted was as described by Black, (1965) and developing the colour in the extract (Motiramani and Wankhede, 1964) using "UV visible Spectrophotometer". The available amount of potassium was determined by using normal neutral ammonium acetate Flame photometer (Black, 1965).

\section{Statistical Analysis}

All the data were subjected to mean and standard deviation to identify the difference among the different treatments for different plant parameters in different treatments.

\section{RESULTS AND DISCUSSION}

Plants have played a major role in maintaining human health and civilizing the value of human life for thousands of years (Dhankar et al., 2011). In the last few years, organic food production became very popular trends. Once more, organic farming ensures safe products for human health as well as for the environment due to the fact that the use of chemical fertilizers and pesticides is not allowed. The experimental findings pertaining to the present investigation i.e. comparative effect of poultry manure and fish manure on the growth parameters and NPK of coriander (Coriandrum sativum L.). The data on influence of various fertilizers on growth parameters were recorded and statistically analyzed in order to find out the impact of different treatments application. Results with respect to various characters in the study are presented under different heads along with Table (1-13) \& Plates 6 \& 7 representation respectively.

\section{Germination}

The data presented in Table (1) revealed the effect of different organic manures effect on plant growth parameters of Coriandrum sativum. Coriander (Coriandrum sativum) seed grown in control $\left(\mathrm{T}_{1}\right)$ garden soil amended without any manure recorded germination percentage as $(80.00 \pm 1.70 \%$ and $66.25 \pm 0.78 \%)$. In soil amended with $25 \%$ poultry manure $\left(\mathrm{T}_{2}\right)$ it showed $(88.76 \pm 0.79 \%)$ of germination, followed by soil amended with $50 \%\left(\mathrm{~T}_{3}\right)$ as $(90.56 \pm 1.57 \%)$. In garden soil amended with $75 \%\left(\mathrm{~T}_{4}\right)$ of poultry manure the germination percentage of Coriandrum sativum recorded was $(78.33 \pm 0.61 \%)$ and in $100 \%\left(\mathrm{~T}_{5}\right)$ it was $52.34 \pm 0.44 \%$ respectively. 
Table: 1 Effect of different concentrations of poultry manure on the germination percentage Of Coriandrum sativum after $30^{\text {th }}$ day of planting

\begin{tabular}{|c|c|c|c|c|c|}
\hline \multirow{2}{*}{$\begin{array}{l}\text { Biometric } \\
\text { characters }\end{array}$} & \multicolumn{5}{|c|}{ TREATMENTS } \\
\hline & $\mathbf{T}_{1}$ & $\mathbf{T}_{2}$ & $\mathbf{T}_{3}$ & $\mathbf{T}_{4}$ & $\mathbf{T}_{5}$ \\
\hline $\begin{array}{c}\text { Germination } \\
(\%)\end{array}$ & $\begin{array}{l}80.00 \\
\pm 1.70\end{array}$ & $\begin{array}{l}88.76 \\
\pm 0.79\end{array}$ & $\begin{array}{l}90.56 \\
\pm 1.57\end{array}$ & $\begin{array}{l}78.33 \\
\pm 0.61\end{array}$ & $\begin{array}{l}52.34 \\
\pm 0.44\end{array}$ \\
\hline
\end{tabular}

*Each value is the mean $\pm \mathrm{SD}$ of three replicates.

From Table (2) the germination $\%$ recorded in fish manure $25 \%$ and $50 \%$ potted soil were $71.42 \pm 1.37 \%\left(\mathrm{~T}_{2}\right) ; 78.17 \pm 1.27 \%\left(\mathrm{~T}_{3}\right)$. In treatments pots $\mathrm{T}_{4}(75 \%)$ and $\mathrm{T}_{5}(100 \%)$, the garden soil amended with fish waste compost recorded germination percentages were $(62.51 \pm 0.31 \%)$ and $(43.17 \pm 0.10 \%)$ respectively.

Table: 2 Effect of different concentrations of fish manure on the germination percentage of Coriandrum sativum after $30^{\text {th }}$ day of planting

\begin{tabular}{|c|c|c|c|c|c|}
\hline \multirow{2}{*}{$\begin{array}{l}\text { Biometric } \\
\text { characters }\end{array}$} & \multicolumn{5}{|c|}{ TREATMENTS } \\
\hline & $\mathbf{T}_{1}$ & $\mathbf{T}_{2}$ & $\mathbf{T}_{3}$ & $\mathbf{T}_{4}$ & $\mathbf{T}_{5}$ \\
\hline $\begin{array}{c}\text { Germination } \\
(\%)\end{array}$ & $\begin{array}{l}66.25 \\
\pm 0.78\end{array}$ & $\begin{array}{l}71.42 \\
\pm 1.37\end{array}$ & $\begin{array}{r}78.17 \\
\pm 1.27\end{array}$ & $\begin{array}{l}62.51 \\
\pm 0.31\end{array}$ & $\begin{array}{l}43.17 \\
\pm 0.10\end{array}$ \\
\hline
\end{tabular}

$*$ Each value is the mean $\pm \mathrm{SD}$ of three replicates.

\section{Number of leaves}

Table (3) revealed the effect of different concentration of poultry manures effect on exomorphological parameter of Coriandrum sativum. Among the treatments $\left(\mathrm{T}_{2} \& \mathrm{~T}_{3}\right)$ i.e. poultry manure $25 \%$ and $50 \%$ amended garden soil grown Coriandrum sativum showed maximum number of leaves $(26.07 \pm 4.41 ; 37.17 \pm 6.15)$ while less number of leaves (14.42 \pm 0.87$)$ were recorded in $100 \%\left(\mathrm{~T}_{5}\right)$. On comparing to control (T1) $19.54 \pm 5.05$ in $75 \%$ poultry manure amended soil grown Coriandrum sativum recorded minimum number of leaves $(16.51 \pm 0.31)$ respectively.

Table: 3 Effect of different concentrations of poultry manure on the number of leaves in Coriandrum sativum after $30^{\text {th }}$ day of treatment.

\begin{tabular}{|c|c|c|c|c|c|}
\hline \multirow{2}{*}{$\begin{array}{l}\text { Biometric } \\
\text { characters }\end{array}$} & \multicolumn{5}{|c|}{ "TREATMENTS } \\
\hline & $\overline{T_{1}}$ & $\overline{T_{2}}$ & $\overline{T_{3}}$ & $\overline{T_{4}}$ & $\overline{T_{5}}$ \\
\hline Number & 19.54 & 26.07 & 37.17 & 1016.51 & 14.42 \\
\hline of Leaves & \pm 5.05 & \pm 4.41 & \pm 6.15 & \pm 0.31 & \pm 0.87 \\
\hline
\end{tabular}

*Each value is the mean \pm SD of three replicates. 
Coriandrum sativum grown in fish manure recorded 17.34 \pm 3.15 (T1)in garden soil without manure while in $25 \%$ and $50 \%$ the number of leaves recorded were $22.17 \pm 3.30\left(\mathrm{~T}_{2}\right)$ and $32.47 \pm 5.03\left(\mathrm{~T}_{3}\right)$ after $30^{\text {th }}$ day of planting. The minimum numbers of leaves recorded after 30th day of transplantation were 14.76 $\pm 0.51\left(\mathrm{~T}_{4}\right)$ and $12.66 \pm 0.37\left(\mathrm{~T}_{5}\right)$ in $75 \%$ and $100 \%$ on comparing to the control pot $(17.34 \pm 3.15)$ grown Coriandrum sativum Table (4) respectively.

Table: 4 Effect of different concentrations of fish manure on the number of leaves in Coriandrum sativum after $30^{\text {th }}$ day of planting.

\begin{tabular}{|c|c|c|c|c|c|}
\hline \multirow{2}{*}{$\begin{array}{l}\text { Biometric } \\
\text { characters }\end{array}$} & \multicolumn{5}{|c|}{ TREATMENTS } \\
\hline & $T_{1}$ & $\mathbf{T}_{2}$ & $\mathbf{T}_{3}$ & $\mathbf{T}_{4}$ & $\mathbf{T}_{5}$ \\
\hline Number & 17.34 & 22.17 & 32.47 & 14.76 & 12.66 \\
\hline of Leaves & \pm 3.15 & \pm 3.30 & \pm 5.03 & \pm 0.51 & \pm 0.37 \\
\hline
\end{tabular}

$*$ Each value is the mean \pm SD of three replicates.

\section{Leaf Area}

From Table (5-6) the data of biometric character (leaf area) of selected herb Coriandrum sativum (Linn.). From the above data it is observed that the Coriandrum sativum (Linn.) grown in 50\% $\left(\mathrm{T}_{3}\right)$ poultry manure amended soil shown greater leaf area $14.58 \pm 2.55 \mathrm{Cm}$ when compared to $50 \%\left(\mathrm{~T}_{3}\right)$ fish manure amended soil grown Coriandrum sativum $12.03 \pm 2.13 \mathrm{Cm}$. In the present observation when comparing with the control grown experimental plant Coriandrum sativum $(10.43 \pm 2.11 \mathrm{Cm} ; 8.00 \pm 0.99)$ the $100 \%$ poultry manure and fish manure soil grown Coriandrum sativum recorded minimum $8.23 \pm 2.09 \mathrm{Cm}$ and $5.38 \pm 1.38 \mathrm{Cm}$ leaf area .

Table: 5 Effect of different concentrations of poultry manure on the leaf area of Coriandrum sativum after $30^{\text {th }}$ day of planting.

\begin{tabular}{|c|c|c|c|c|c|}
\hline \multirow{2}{*}{$\begin{array}{l}\text { Biometric } \\
\text { characters }\end{array}$} & \multicolumn{5}{|c|}{ TREATMENTS } \\
\hline & $\overline{T_{1}}$ & $\overline{T_{2}}$ & $\overline{T_{3}}$ & $\overline{T_{4}}$ & $\overline{T_{5}}$ \\
\hline $\begin{array}{l}\text { Leaf Area } \\
(\mathrm{Cm})\end{array}$ & $\begin{array}{l}10.43 \\
\pm 2.11\end{array}$ & $\begin{array}{l}10.63 \\
\pm 2.38\end{array}$ & $\begin{array}{r}14.58 \\
\pm 2.55\end{array}$ & $\begin{array}{c}9.27 \\
\pm 2.23\end{array}$ & $\begin{array}{c}8.23 \\
\pm 2.09\end{array}$ \\
\hline
\end{tabular}

*Each value is the mean \pm SD of three replicates. 
Table: 6 Effect of different concentrations of fish manure on the leaf area of Coriandrum sativum after $30^{\text {th }}$ day of planting.

\begin{tabular}{|c|c|c|c|c|c|}
\hline \multirow{2}{*}{$\begin{array}{l}\text { Biometric } \\
\text { characters }\end{array}$} & \multicolumn{5}{|c|}{ TREATMENTS } \\
\hline & $\overline{T_{1}}$ & $\overline{T_{2}}$ & $\overline{T_{3}}$ & $\overline{T_{4}}$ & $\overline{T_{5}}$ \\
\hline $\begin{array}{l}\text { Leaf Area } \\
(\mathrm{Cm})\end{array}$ & $\begin{array}{c}8.00 \\
\pm 0.99\end{array}$ & $\begin{array}{l}10.30 \\
\pm 1.43\end{array}$ & $\begin{array}{l}12.03 \\
\pm 2.13\end{array}$ & $\begin{array}{c}7.60 \\
\pm 2.01 \\
\end{array}$ & $\begin{array}{c}5.83 \\
\pm 1.38\end{array}$ \\
\hline
\end{tabular}

*Each value is the mean \pm SD of three replicates.

Next to control grown pot the herb Coriandrum sativum (Linn.) grown $75 \%$ poultry manure $\left(\mathrm{T}_{4}\right)$ amended soil pot showed moderate leaf area $(9.27 \pm 2.23 \mathrm{Cm})$. Among the selected treatments fish waste compost $\left(\mathrm{T}_{4}\right)$ by Eudrilus euginea amended soil grow Coriandrum sativum (Linn.) showed least leaf length $(7.60 \pm 2.01 \mathrm{Cm})$ respectively after $30^{\text {th }}$ day of planting.

\section{Plant height}

The prime exomorphological character plant height $(\mathrm{mm})$ of selected herb Coriandrum sativum are presented in Table (7 -8). It is observed that the Coriandrum sativum (Linn.) grown in poultry manure amended soil $\left(\mathrm{T}_{3}\right) 50 \%$ shown greater plant height $(75.50 \pm$ $1.22 \mathrm{~mm})$ followed by $\left(\mathrm{T}_{2}\right) 50 \%(69.50 \pm 2.62 \mathrm{~mm})$. Minimum height was observed in $\left(\mathrm{T}_{4}\right)$ $75 \%(63.91 \pm 1.17)$ when compared to the control $\left(\mathrm{T}_{1}\right)(67.70 \pm 1.75 \mathrm{~mm})$ pot grown plant not amended with manure. Among the treatment of selected concentrations, soil amended with $100 \%\left(\mathrm{~T}_{5}\right)$ poultry manure recorded the least plant height $(56.50 \pm 2.03 \mathrm{~mm})$ respectively.

Table: 7 Effect of different concentrations of poultry manure on the plant height of Coriandrum sativum after $30^{\text {th }}$ day of planting.

\begin{tabular}{|c|c|c|c|c|c|}
\hline \multirow{2}{*}{$\begin{array}{l}\text { Biometric } \\
\text { characters }\end{array}$} & \multicolumn{5}{|c|}{ TREATMENTS } \\
\hline & $T_{1}$ & $\mathbf{T}_{2}$ & $\mathbf{T}_{3}$ & $\mathbf{T}_{4}$ & $\mathbf{T}_{5}$ \\
\hline $\begin{array}{l}\text { Plant Height } \\
(\mathrm{mm})\end{array}$ & $\begin{array}{l}67.70 \\
\pm 1.75\end{array}$ & $\begin{array}{l}69.50 \\
\pm 2.62\end{array}$ & $\begin{array}{r}75.50 \\
\pm 1.22\end{array}$ & $\begin{array}{l}63.91 \\
\pm 1.17\end{array}$ & $\begin{array}{l}56.50 \\
\pm 2.03\end{array}$ \\
\hline
\end{tabular}

*Each value is the mean $\pm \mathrm{SD}$ of three replicates. 
Table: 8 Effect of different concentrations of fish manure on the plant height of Coriandrum sativum after $30^{\text {th }}$ day of planting

\begin{tabular}{|c|c|c|c|c|c|}
\hline \multirow{2}{*}{$\begin{array}{c}\text { Biometric } \\
\text { characters }\end{array}$} & \multicolumn{5}{|c|}{ TREATMENTS } \\
\hline & $\overline{T_{1}}$ & $\overline{T_{2}}$ & $\mathbf{T}_{3}$ & $\overline{T_{4}}$ & $\bar{T}_{5}$ \\
\hline $\begin{array}{c}\text { Plant Height } \\
(\mathrm{Cm})\end{array}$ & $\begin{array}{l}27.98 \\
\pm 6.47\end{array}$ & $\begin{array}{l}29.78 \\
\pm 5.75\end{array}$ & $\begin{array}{l}31.42 \\
\pm 6.62\end{array}$ & $\begin{array}{l}22.12 \\
\pm 4.69\end{array}$ & $\begin{array}{l}18.67 \\
\pm 4.47\end{array}$ \\
\hline
\end{tabular}

*Each value is the mean \pm SD of three replicates.

In the treatment pot amended with fish manure the selected experimental plant Coriandrum sativum (Linn.) showed the maximum plant height $(31.2 \pm 6.62 \mathrm{~mm})$ in potted soil amended with $50 \%\left(\mathrm{~T}_{3}\right)$ fish manure. On the other hand Coriandrum sativum grown in only garden soil (ie) control $\left(\mathrm{T}_{1}\right)$ recorded $(27.98 \pm 6.47 \mathrm{~mm})$. Among the selected treatments fish waste compost of $75 \%$ and $100 \%\left(\mathrm{~T}_{4} \& \mathrm{~T}_{5}\right)$ amended soil grown Coriandrum sativum (Linn) showed minimum plant height $(22.12 \pm 4.69 \mathrm{~mm})$ and $(18.67 \pm 4.47 \mathrm{~mm})$ respectively Table 8. The herb Coriandrum sativum (Linn.) grown in pot soil amended with $25 \%$ fish manure showed maximum plant height $(29.78 \pm 5.75 \mathrm{~mm})$ next to $50 \%$ grown herb respectively.

\section{Number of branches}

Table: 9 Effect of different concentrations of poultry manure on the number of branches in Coriandrum sativum after $30^{\text {th }}$ day of planting.

\begin{tabular}{|c|c|c|c|c|c|}
\hline \multirow{2}{*}{$\begin{array}{l}\text { Biometric } \\
\text { characters }\end{array}$} & \multicolumn{5}{|c|}{ TREATMENTS } \\
\hline & $\overline{T_{1}}$ & $\overline{T_{2}}$ & $\overline{T_{3}}$ & $\overline{\mathbf{T}_{4}}$ & $\overline{T_{5}}$ \\
\hline No of & 12.28 & 12.62 & 13.12 & 12.20 & 9.91 \\
\hline Branches & \pm 1.10 & \pm 0.55 & \pm 2.39 & \pm 1.35 & \pm 2.57 \\
\hline
\end{tabular}

*Each value is the mean \pm SD of three replicates.

Table (9) shows the data of biometric character (number of branches) of selected herb Coriandrum sativum (Linn.). From the above data it in observed that the Coriandrum sativum (Linn.) grown in poultry manure amended soil shown greater number of branches $(12.62 \pm 0.55 ; 13.12 \pm 2.39)$ in pots amended with $25 \%$ and $50 \%$ of manures. Next to $\mathrm{T}_{2}$ and $\mathrm{T}_{3}$ amended soil grown herb Coriandrum sativum(Linn.) the $\mathrm{T}_{4}(75 \%)$ amended soil grow plant showed maximum number of branches $(12.20 \pm 1.35)$ which was followed by $100 \%$ manure amended grown Coriandrum sativum (9.91 \pm 2.57$)$. 
Table: 10 Effect of different concentrations of fish manure on the number of branches in Coriandrum sativum after $30^{\text {th }}$ day of planting.

\begin{tabular}{|c|c|c|c|c|c|}
\hline \multirow{2}{*}{$\begin{array}{l}\text { Biometric } \\
\text { characters }\end{array}$} & \multicolumn{5}{|c|}{ TREATMENTS } \\
\hline & $\overline{T_{1}}$ & $\overline{T_{2}}$ & $\mathbf{T}_{3}$ & $\overline{T_{4}}$ & $\overline{T_{5}}$ \\
\hline $\begin{array}{c}\text { No of } \\
\text { Branches }\end{array}$ & $\begin{array}{c}6.24 \\
\pm 0.93\end{array}$ & $\begin{array}{c}6.85 \\
\pm 0.85\end{array}$ & $\begin{array}{c}8.41 \\
\pm 0.58\end{array}$ & $\begin{array}{c}6.00 \\
\pm 1.24\end{array}$ & $\begin{array}{c}5.32 \\
\pm 0.47\end{array}$ \\
\hline
\end{tabular}

*Each value is the mean $\pm \mathrm{SD}$ of three replicates.

The fish waste compost composed by Eudrilus euginea amended soil grow Coriandrum sativum (Linn.) showed least number of branches $(5.32 \pm 0.47)$ and $(6.00 \pm 1.24)$ i.e. $\mathrm{T}_{5} \& \mathrm{~T}_{4}$ concentrations grown plant after $30^{\text {th }}$ day after planting. Comparing to the following selected treatments the experimental plant grown in garden soil amended pot i.e. Control $\left(T_{1}\right)$ showed minimum number of branches $(6.24 \pm 0.41)$ than other manure concentration treated pot. The maximum number of branches $6.85 \pm 0.85\left(\mathrm{~T}_{2}\right)$ and $8.41 \pm 0.58$ $\left(\mathrm{T}_{3}\right)$ was recorded in $25 \%$ and $50 \%$ fish manure amended garden soil grown Coriandrum sativum (Linn.) respectively.

\section{Root length}

Data presented in Table $(11 \& 12)$ show that the effect of different treatments $25 \%$ $100 \%$ influenced significantly on root length. From the data mean comparison (Table 11) shows that the best treatment for increasing the root length $\left(\mathrm{T}_{2}\right) 25 \%$ and $\left(\mathrm{T}_{3}\right) 50 \%$ i.e poultry $(19.91 \pm 1.90 \mathrm{~mm} ; 26.30 \pm 1.98 \mathrm{~mm})$ and fish manure (Table 12) $(17.09 \pm 1.10 \mathrm{~mm}$; $22.11 \pm 1.58 \mathrm{~mm}$ ) amended pot grown Coriandrum sativum which showed maximum root length.

Table: 11 Effect of different concentration of poultry manures on the root length in Coriandrum sativum after $30^{\text {th }}$ day of planting.

\begin{tabular}{|c|c|c|c|c|c|}
\hline \multirow{2}{*}{$\begin{array}{l}\text { Biometric } \\
\text { characters }\end{array}$} & \multicolumn{5}{|c|}{ TREATMENTS } \\
\hline & $\overline{T_{1}}$ & $\overline{\mathbf{T}_{2}}$ & $\overline{T_{3}}$ & $\overline{T_{4}}$ & $\overline{\mathbf{T}_{5}}$ \\
\hline $\begin{array}{l}\text { Root length } \\
\text { (mm) }\end{array}$ & $\begin{array}{l}14.01 \\
\pm 0.26\end{array}$ & $\begin{array}{l}19.91 \\
\pm 1.90\end{array}$ & $\begin{array}{l}26.30 \\
\pm 1.98\end{array}$ & $\begin{array}{l}11.52 \\
\pm 1.23\end{array}$ & $\begin{array}{c}9.01 \\
\pm 0.16\end{array}$ \\
\hline
\end{tabular}

*Each value is the mean \pm SD of three replicates.

A perusal of Table (11) and also revealed that the root length of seedling of Coriander (Coriandrum sativum) was found to be $(14.01 \pm 0.26 \mathrm{~mm} ; 11.45 \pm 0.16 \mathrm{~mm})$ in control soil $\left(\mathrm{T}_{1}\right)$. The herb Coriandrum sativum grown in poultry manure $\left(\mathrm{T}_{4}\right)$ amended soil recorded 
$(11.52 \pm 1.23 \mathrm{~mm})$ root length and $(9.55 \pm 1.13 \mathrm{~mm})$ in fish manure $\left(\mathrm{T}_{4}\right)$ amended soil. Whereas plant grown in $100 \%$ poultry manure and fish manure amended soil was noted to be $(9.01 \pm 0.16 \mathrm{~mm})$ and $(6.32 \pm 0.15 \mathrm{~mm})$ root length after $30^{\text {th }}$ day of planting. On the other hand coriander plant grown in fish waste $\left(\mathrm{T}_{5}\right)$ compost recorded $(6.32 \pm 0.15 \mathrm{~mm})$ root length while the root length $(9.01 \pm 0.16 \mathrm{~mm})$ grown in poultry waste compost amended garden soil respectively.

Table: 12 Effect of different concentration of fish manures on the root length in Coriandrum sativum after $30^{\text {th }}$ day of planting.

\begin{tabular}{|c|c|c|c|c|c|}
\hline \multirow{2}{*}{$\begin{array}{l}\text { Biometric } \\
\text { characters }\end{array}$} & \multicolumn{5}{|c|}{ TREATMENTS } \\
\hline & $\overline{T_{1}}$ & $\overline{T_{2}}$ & $\overline{T_{3}}$ & $\overline{T_{4}}$ & $\overline{T_{5}}$ \\
\hline $\begin{array}{l}\text { Root length } \\
\text { (mm) }\end{array}$ & $\begin{array}{l}11.45 \\
\pm 0.16\end{array}$ & $\begin{array}{l}17.09 \\
\pm 1.10\end{array}$ & $\begin{array}{l}22.11 \\
\pm 1.58\end{array}$ & $\begin{array}{c}9.55 \\
\pm 1.13\end{array}$ & $\begin{array}{c}6.32 \\
\pm 0.15\end{array}$ \\
\hline
\end{tabular}

*Each value is the mean \pm SD of three replicates.

\section{Nutrient Parameters}

Soil nutrient management is necessary to maintain the constant productivity as well as good quality soil. Animal manure is a valuable resource as a soil fertilizer because it provides large amounts of macro and micronutrients for crop growth and is available at low-cost. In addition these manures are environmentally-friendly and alternative to mineral fertilizers.

In the present study the maximum nitrogen recorded was $2.9 \pm 1.18 \%$ and $2.0 \pm 1.14$ $(\%)$ in $\mathrm{T}_{3}$ concentration i.e $50 \%$ of the poultry manure and fish manure amended pot grown Coriandrum sativum while the minimum percentage of $0.9 \pm 0.16 \%$ and $0.3 \pm 0.13 \%$ was noted in $\mathrm{T}_{5}$ treatment $100 \%$ poultry and fish manure amended potted plants. Similarly the macro nutrients like phosphate $11.3 \pm 0.21 \% ; 10.5 \pm 0.05 \%$ and potassium $5.4 \pm 0.25 \%$ and $3.15 \pm 0.22 \%$ too was recorded high in $\mathrm{T}_{3}$ followed by $\mathrm{T}_{2}$ concentration grown garden soil amended with poultry and fish manure after $30^{\text {th }}$ day of planting.

Table: 13 Effect of different concentration of poultry manures on the NPK content in Coriandrum sativum after $30^{\text {th }}$ day of planting.

\begin{tabular}{|c|c|c|c|c|c|}
\hline \multirow{2}{*}{$\begin{array}{l}\text { Nutrient } \\
\text { parameter }\end{array}$} & \multicolumn{5}{|c|}{ TREATMENTS } \\
\hline & $\overline{T_{1}}$ & $\bar{T}_{2}$ & $\overline{T_{3}}$ & $\overline{T_{4}}$ & $\bar{T}_{5}$ \\
\hline $\begin{array}{c}\text { Nitrogen } \\
(\%)\end{array}$ & $\begin{array}{c}1.5 \\
\pm 0.2\end{array}$ & $\begin{array}{c}2.1 \\
\pm 0.10\end{array}$ & $\begin{array}{c}2.9 \\
\pm 1.18\end{array}$ & $\begin{array}{c}1.2 \\
\pm 1.23\end{array}$ & $\begin{array}{c}0.9 \\
\pm 0.16\end{array}$ \\
\hline $\begin{array}{c}\text { Phosphate } \\
(\%)\end{array}$ & $\begin{array}{c}9.2 \\
\pm 0.11\end{array}$ & $\begin{array}{c}10.9 \\
\pm 0.19\end{array}$ & $\begin{array}{c}11.3 \\
\pm 0.21\end{array}$ & $\begin{array}{c}8.9 \\
\pm 0.44\end{array}$ & $\begin{array}{c}7.8 \\
\pm 0.58 \\
\end{array}$ \\
\hline $\begin{array}{c}\text { Potassium } \\
(\%)\end{array}$ & $\begin{array}{c}3.5 \\
\pm 0.77\end{array}$ & $\begin{array}{c}4.0 \\
\pm 0.52\end{array}$ & $\begin{array}{c}5.4 \\
\pm 0.25\end{array}$ & $\begin{array}{c}2.8 \\
\pm 0.63\end{array}$ & $\begin{array}{c}1.7 \\
\pm 0.72\end{array}$ \\
\hline
\end{tabular}

*Each value is the mean $\pm \mathrm{SD}$ of three replicates. 
Table: 14 Effect of different concentration of fish manures on the NPK content in Coriandrum sativum after $30^{\text {th }}$ day of planting.

\begin{tabular}{|c|c|c|c|c|c|}
\hline \multirow{2}{*}{$\begin{array}{c}\text { Nutrient } \\
\text { parameter }\end{array}$} & \multicolumn{5}{|c|}{ TREATMENTS } \\
\hline & $\overline{T_{1}}$ & $\overline{T_{2}}$ & $\mathbf{T}_{3}$ & $\overline{T_{4}}$ & $\overline{T_{5}}$ \\
\hline $\begin{array}{c}\text { Nitrogen } \\
(\%)\end{array}$ & $\begin{array}{c}1.0 \\
\pm 0.3 \\
\end{array}$ & $\begin{array}{c}1.6 \\
\pm 0.9 \\
\end{array}$ & $\begin{array}{c}2.0 \\
\pm 1.14\end{array}$ & $\begin{array}{c}0.9 \\
\pm 1.26 \\
\end{array}$ & $\begin{array}{c}0.3 \\
\pm 0.13 \\
\end{array}$ \\
\hline $\begin{array}{c}\text { Phosphate } \\
(\%)\end{array}$ & $\begin{array}{c}8.4 \\
\pm 0.11\end{array}$ & $\begin{array}{c}9.8 \\
\pm 0.01\end{array}$ & $\begin{array}{c}10.5 \\
\pm 0.05\end{array}$ & $\begin{array}{c}7.9 \\
\pm 0.12\end{array}$ & $\begin{array}{c}6.3 \\
\pm 0.19\end{array}$ \\
\hline $\begin{array}{l}\text { Potassium } \\
(\%)\end{array}$ & $\begin{array}{c}2.67 \\
\pm 0.07\end{array}$ & $\begin{array}{c}2.89 \\
\pm 0.13\end{array}$ & $\begin{array}{c}3.15 \\
\pm 0.22\end{array}$ & $\begin{array}{c}2.49 \\
\pm 0.43\end{array}$ & $\begin{array}{c}2.35 \\
\pm 0.37\end{array}$ \\
\hline
\end{tabular}

*Each value is the mean \pm SD of three replicates.

On comparing with Control plant $\left(\mathrm{T}_{1}\right) 1.5 \pm 0.2 ; 9.2 \pm 0.11 ; 3.5 \pm 0.77$ of NPK levels $\mathrm{T}_{4}$ $(75 \%)$ treated Coriandrum sativum herb after $30^{\text {th }}$ day of planting recorded less amount of NPK $1.23 \pm 1.23 ; 8.9 \pm 0.44 ; 2.8 \pm 0.63$ in poultry waste treated potted plant. In fish manure treated plant the NPK levels $\mathrm{T}_{4}(75 \%)$ treated Coriandrum sativum herb after $30^{\text {th }}$ day of planting recorded were $0.96 \pm 1.26 ; 7.9 \pm 0.12$ and $2.49 \pm 0.43$ which was noted to be less than control $\left(\mathrm{T}_{1}\right)$ plant $1.0 \pm 0.3 ; 8.4 \pm 0.11$ and $2.67 \pm 0.07$ respectively.

50.9 million hectare under organic culture and 2.4 million producers working in this sector. 12.7 million hectare land under organic agriculture in Asia. The share of world's organic agricultural land is 1.1 percent. Country with most organic agriculture producers are India $(5,85,200)$. Asia has $4^{\text {th }}$ rank with 4 million hectare land that comprises $8 \%$ of world's organic agricultural land. India has $9^{\text {th }}$ rank in organic agriculture land in the world. India has $1^{\text {st }}$ position as producer of organic products worldwide

From the above experimental results it authentically proves that the organic manures like poultry manure and fish manure is considered to be the best, active and cheapest source of plant nutrients which could be considered as efficient manure that helps in maintaining soil fertility. Soil, the soul of infinite lives that promotes diverse micro flora primarily holds earthworms, the "farmer's friend" or "nature's ploughman". It influences the physical and chemical properties of soil.

Thus from the present study results the data revealed that increase in plant growth, i.e. germination percentage, plant height, leaf area, branches number, leaf number and root length 
could probably be due to improvement in the physicochemical properties of soil; increase in enzymatic activity; increase in microbial population, diversity and activity; easy availability of macro and micronutrients; and also increase in plant growth hormones by application of poultry manure and fish manure. According to Stephen Oyedeji et al., 2014 Organic fertilizer ie poultry manure (PM) generally increased the growth of all the plant species. The significant increase in the mean values of selected exomorphological parameter was observed in poultry grown $\left(\mathrm{T}_{3} \& \mathrm{~T}_{2}\right)$ Coriandrum sativum when compared to control $\left(\mathrm{T}_{1}\right)$ which was similar to the results obtained Ayeni et al., 2012 who stated that poultry manure also contains useful soil nutrients that are needed for the growth of plants but their composition is in the crude form that is released slowly to the soil

The increase in leaf area, root length, number of leaves and branches in poultry amended soil grow Coriandrum sativum may be due to soluble bacteria which are present in it which may generate soil soluble phosphorus, secretion of plant growth hormones, natural enzymes, antibiotics and different essential compounds which are capable to develop the aerial parts of plant. This statement was supported by Astaraei and Koocheki, 1997 who stated that application of biological fertilizer will help to sustain agriculture. Poultry manure has traditionally been treated as a waste product and applied to surrounding crop and pasturelands to recycle nutrients, primarily nitrogen $(\mathrm{N})$, phosphorus $(\mathrm{P})$, and potash $(\mathrm{K})$ (Lorimor and Xin, 1999). Therefore, the number of leaves and leaf area may not behave in association however, they can follow similar trend partially due to variations in the individual growth of leaf laminae. In the present study, it is observed that though not very strong there are an association between the number of leaves and leaf area i.e. more the leaves in a genotype maximum is the leaf area per plant or at least on par with the most superior accession. The observations recorded by Banerjee and Kole (2004) and Mourya et al. (2015) in fenugreek for grain yield per plant were also in conformity with this

Poultry manure is often applied to meet the crop nitrogen requirement, resulting in excessive $\mathrm{P}$ application. While the agronomic benefits are well established, the environmental aspects of poultry manure management have primarily focused on water quality (Harmel et al., 2009; Vervoort et al., 1998). A more comprehensive assessment of poultry manure usage in agro-ecosystems considers crop yield, soil health, and water quality, as well as the economic impact of integrating poultry manure into cropping systems. Economic factors are 
of paramount importance as they are a primary, if not the leading factor driving farm-scale decision-making.

The biometric parameters recorded from the experimental plant with fish waste fertilizer is as comparable to the results of Lazcano et al., 2008. The fermented fish waste was found to be biological preparations as sufficient source of micronutrients and microorganisms. It has beneficial microbes for the growth of Coriandrum sativum which has promoted the plant growth via root length and nodulation when compared with fish wastes which was similar to the findings of Hoover et al., 2015. Moreover processing of this fish waste material through controlled bio-oxidation processes, such as composting, reduces the environmental risk by transforming the material into a safer and more stable product suitable for application to soil (Lazcano et al., 2008), and also reduces the transportation costs because of the significant reduction in the water content of the raw organic matter. Application of unstable or immature compost may inhibit seed germination, reduce plant growth and damage crops by competing for oxygen or causing phytotoxicity to plants due to insufficient biodegradation of organic matter (Wu et al., 2000; Brewer and Sullivan, 2003 and Cooperband et al., 2003).

Plants with higher yield remove high N, P and K from the soil. A positive relationship was observed between uptake of the major nutrients and yield, probably through better uptake of $\mathrm{N}, \mathrm{P}$ and $\mathrm{K}$ and their utilization in protein synthesis. In the present study the plant in $\mathrm{T}_{3}$ which recorded maximum number of leaves, branches, larger; leaf area, height and root length recoded higher concentration of nitrogen $2.9 \pm 1.18 \%$ and $2.0 \pm 1.14$; phosphate $11.3 \pm 0.21 \% ; 10.5 \pm 0.05 \%$ and potassium $5.4 \pm 0.25 \%$ and $3.15 \pm 0.22 \%$. Deora and Singh, (2008) revealed that the application of fertilizer significantly increased the N, P, K contents and there uptake by crop. Channabasavanna, (2002), Salem and Awad, (2005); Tripathi, (2006) observed similar result.

Poultry manure is an organic fertilizer source that benefits yield, soil health, and overall farm income, and thus can be viewed as a regionally marketable resource (Janzen et al., 1999). Organic manure increased soil $\mathrm{pH}$, the concentrations of nitrogen, phosphorus, and major cations. Potassium $(\mathrm{K})$ is the second most important nutrient element next to nitrogen for growth and development of spices crops. Plant absorbs potassium in its ionic form, $\mathrm{K}+$. Potassium is an essential nutrient for proper growth, root development and seed and fruit 
development and reproduction of plant. It affects the plant size, shape, colour, taste and other measurement attributed to healthy production. Potassium promotes increased root growth and thicker cell walls. After N, P is the second most frequently limiting macronutrient for plant growth. Phosphate is mostly presence in soil which is uptake by plant using specific transporter present in a cell membrane. Phosphate is an important macronutrient in a plant making up about $0.2 \%$ of a plants dry weight. It is a component key of nucleic acids, carbohydrate, phospholipids, ATP. Plants cannot grow without a reliable supply of the nutrient. Phosphate is one 17 nutrients essential for plant growth. Gascho and Hubbard, (2006) reported increased soil phosphate in sandy soils after seven years of broiler manure application. Major cations, including potassium, and nitrogen and phosphorus were increased by organic manure treatment due to their high content in organic manure. Application of animal waste manures, which contain both mineral and organic nitrogen, is useful for maintaining and improving soil fertility and rice production (Takahashi, Uenosono, and Nagatomo 2004). The plant accumulations of $\mathrm{P}$ and $\mathrm{K}$ were significantly different between the soils and among treatments in both years (Table 5). Significantly greater plant accumulation of $\mathrm{P}$ and $\mathrm{K}$ were observed in poultry manure than fish manure application.

\section{CONCLUSION}

Organic manures provide a stable organic matter that improves the physical, chemical, and biological properties of soils, thereby enhancing soil quality and crop production. When correctly applied, the organic manures will have beneficial effects on soil properties, thus creating suitable conditions for root development and consequently promoting higher yield and higher quality of crops. One of the unique features of organic manure is that during the process of conversion of various organic wastes by earthworms, many of the nutrients are changed to their available forms in order to make them easily utilizable by plants. Therefore, organic manures have higher level of available nutrients like nitrate or ammonium nitrogen, exchangeable phosphorous and soluble potassium, calcium and magnesium derived from the wastes (Buchanan et al., 1988). The significant increase in all growth parameters in poultry manure treated potted plants than fish manure may be due to the significant increase in the absorption of major plant nutrients such as $\mathrm{N}, \mathrm{P}$ and $\mathrm{K}$ by plants. This clearly indicates that poultry manure is highly suitable than fish manure for quick absorption of the major nutrients and provides enhanced nourishment for plants. Thus, the 
present results clearly suggest that poultry manure and fish manure can be employed in sustainable farming practices and farmers are request to avoid using chemical fertilizers which reduces or even eradicates the beneficial nutrients and a microorganism present in the soil and reduces the nutrient availability necessary for plant growth.

\section{BIBLIOGRAPHY}

1. Astaraei, A. and A. Koocheki, (1997). Application of biological fertilizers in Sustainable agriculture. Mashhad Jehad. Daneshgahi Press. First Edition. (Translate).

2. Ayeni, L. S., E. O. Adeleye, and J. O. Adejumo.( 2012). Comparative effect of organic, organo-mineral and mineral fertilizers on soil properties, nutrient uptake, growth and yield of maize (Zea mays), International Research Journal of Agricultural Science and Soil Science, 2(11):493-497.

3. Banerjee, P.C. Kole. (2004). Analysis of genetic divergence in fenugreek (Trigonella foenumgraecum L. J. Spices Aromat. Crops, 13: 49-51.

4. Black, C.A. (1965). Method of plant and soil analysis part-II pub Amer. Sco. Agron.Madison, Wiscorsin, USA. PP.1367-1373.

5. Brewer, L.J., Sullivan, D.M., (2003). Maturity and stability evaluation of composted yard trimmings. Compost Science and Utilization, 11 (2): 96-112.

6. Buchanan MA, Russelli E, Block SD (1988). Chemical characterization and nitrogen mineralization potentials of vermicomposts derived from differing organic wastes, in Earthworms in Environmental and waste Management, (eds C. A. Edwards and E. F. Neuhauser), SPB Acad, Publ., The Netherlands, pp. 231-9.

7. Channabasavanna, A.S. (2002). Standardization and economic analysis of fertilizer levels for coriander (Coriandrum sativumL.). J. Maharashtra Agril. Univer., 27(2): 160-162.

8. Cooperband, L.R., Stone, A.G., Fryda, M.R., Ravet, J.L., (2003). Relating compost measures of stability and maturity to plant growth. Compost Science \& Utilization 11 (2): 113-124.

9. Deora, N.S. and Singh, J. (2008). Effect of integrated nutrient management and seed rate on quality of fenugreek (Trigonella corniculata L.) cv. Kasuri and post-harvest soil fertility status in loamy sand soil of Rajasthan. Environ. \& Ecol., 26(4A): 1749-1752.

10. Dhankar, S. Kaur, R. Ruhil, S. Balhara, M. Dhankhar, S. Chhillar, A.K. (2011). A review on Justicia adhatoda a potential source of natural medicine. African Journal of Plant Science, 620-627.

11. Gascho.G.J., R.K. Hubbard. (2006). Long-term impact of broiler litter on chemical properties of a Coastal Plain soilJ. Soil Water Conserv., 61 (2): L65-L74.

12. Grubinger, Vernon P. (1999). Sustainable vegetable production from start-up to market. Ithaca, N.Y.: Natural Resource, Agriculture, and Engineering Service, Cooperative Extension. Natural Resource, Agriculture, and Engineering Service (NRAES). Book Chapter.

13. Harmel. R.D., D.R. Smith, R.L. Haney, M. Dozier. (2009). Nitrogen and phosphorus runoff from cropland and pasture fields fertilized with poultry litter. J. Soil Water Conserv., 64 (6): 400-412.

14. Hartz, T.K. and Hochmuth, G.J. (1996). Fertility management of drip irrigated vegetables. Hort. Tech., 6:168.

15. Hoover, N.L., R. Kanwar, M.L. Soupir, C. Pederson. (2015). Effects of poultry manure application on phosphorus in soil and tile drain water under a corn-soybean rotation. Water Air Soil Pollut., 226:138.

16. Janzen. R.A., W.B. McGill, J.J. Leonard, S.R. Jeffrey. (1999). Manure as a resource - ecological and economic consideration in balance Trans. ASAE (Am. Soc. Agric. Eng.), 42: 1261-1273.

17. Lazcano, C., Gómez-Brandón, M. and Domínguez, J. (2008). Comparison of the effectiveness of composting and vermicomposting for the biological stabilization of cattle manure. Chemosphere, 72 : 1013-1019

18. Lorimor. J. C., H. Xin. (1999). Manure production and nutrient concentrations from highrise layer house. Applied Engineering in Agriculture, 15(4): 337-340.

19. Motiramani, S.A. and Wankhede, P.K. (1964). Soil nutrients bio-variability a mechanist approach. John Wiley and Sons, Bombay, (M.S.) India.

20. Mourya, P.B, Yadav, K.B, Pandey, P.V. and Yadav S.P. (2015). Correlation and path analysis in Fenugreek (Trigonella foenumgraecum L.). Research of Environmental Life Science. 8(4): 569-70.

21. Olsen, S.R., Cale, C.V., Watonable, F.S. and Dean, L.A. (1954). Estimation of available phosphorus in soil by extraction with sodium bicarbonate. Circular No. 939 - Washington. 
22. Salem, A.G. and Awad, A.M. (2005). Response of coriander plants to organic and mineral fertilizers fustigated in sandy soils. Egyptian J. Agril. Res., 83(2): 829-858.

23. Stephen Oyedeji, David Adedayo Animasaun, Abdullahi Ajibola Bello, and Oludare Oladipo Agboola.(2014). Effect of NPK and poultry manure on growth, yield, and proximate composition of three amaranths. https://doi.org/10.1155/2014/828750.

24. Subbian, B.V. and Asija, G.L. (1956). A rapid procedure for estimation of available nitrogen in soils. Curr.sci., 25: 259-260.

25. Takahashi, S., S. Uenosono, and M. Nagatomo. (2004). Rice uptake of nitrogen form aerobically and anaerobically composted poultry manure. Journal of Plant Nutrition 27:731-741

26. Tripathi, M.L. (2006). Effect of potassium and sulphur levels on yield and uptake of $N, P$ and $K$ by coriander. Crop Res. (Hisar), 32 (3): 370-371.

27. Vervoort. R.W., D.E. Radcliffe, M.L. Cabrera, M. Latimore, Jr. Field. (1998). Scale nitrogen and phosphorus losses from hayfields receiving fresh and composted broiler litter. J. Environ. Qual., 27 (5): 1246-1254.

28. Wu, L., L.Q. Ma and G.A. Martinez. (2000). Comparison of methods for evaluating stability and maturity of biosolids compost. J. Environ. Qual., 29: 424-429. 